\title{
Hormones, metabolites, and reproduction in Holsteins, Jerseys, and their crosses
}

\author{
K. L. Brown, B. G. Cassell, M. L. McGilliard, M. D. Hanigan, and F. C. Gwazdauskas ${ }^{1}$ \\ Department of Dairy Science, Virginia Polytechnic Institute and State University, Blacksburg 24061-0315
}

\begin{abstract}
Holsteins (HH), Jerseys (JJ), and their crosses in first $(\mathrm{n}=157)$ and second $(\mathrm{n}=107)$ lactation were used to determine if reproduction, progesterone (P4), insulinlike growth factor 1 (IGF-1), insulin, nonesterified fatty acids (NEFA), and milk production differed between genetic groups. Thirty-four cows were Holstein-Jersey (HJ) crosses, 46 were Jersey-Holstein $(\mathrm{JH})$ crosses, 48 were purebred Holsteins $(\mathrm{HH})$, and 29 were purebred Jerseys (JJ) in first lactation, whereas the secondlactation animals included $23 \mathrm{HJ}, 35 \mathrm{JH}, 35 \mathrm{HH}$, and 14 JJ. Blood samples were collected weekly for the first 10 wk postpartum. Analyses were conducted using the MIXED, chi-square, and GLIMMIX procedures (SAS Institute Inc., Cary, NC). Seasons of calving were cold (November to May) and hot (June to October) and were combined with year to form 8 year-seasons. Days open and number of services were affected by genetic group. The $\mathrm{HH}$ were open $169 \pm 8 \mathrm{~d}$, which was greater than HJ (143 \pm 9 d), JJ $(132 \pm 10 \mathrm{~d})$, and JH $(127 \pm 8$ d). The HH had $2.4 \pm 0.1$ services per pregnancy, which was greater than $\mathrm{JH}(1.9 \pm 0.1)$, but not different from HJ $(2.1 \pm 0.2)$ or JJ $(2.1 \pm 0.2)$. Concentrations of NEFA were greater in lactation $2(0.52 \pm 0.02 \mathrm{mEq} / \mathrm{L})$ than in lactation $1(0.45 \pm 0.02 \mathrm{mEq} / \mathrm{L})$ and decreased over the 10-wk period. Concentrations of NEFA were greater in the cold season except in yr 3. Insulin in lactation $1(0.81 \pm 0.03 \mathrm{ng} / \mathrm{mL})$ was greater than in lactation $2(0.72 \pm 0.03 \mathrm{ng} / \mathrm{mL})$; insulin decreased to wk 2 then gradually increased. The HJ had the greatest insulin concentrations $(0.87 \pm 0.04 \mathrm{ng} / \mathrm{mL})$ and the JJ had the lowest $(0.66 \pm 0.04 \mathrm{ng} / \mathrm{mL})$, and IGF-1 gradually increased over the 10 -wk period. Milk production (actual yield in the first $305 \mathrm{~d}$, not adjusted for fat and protein) was affected by genetic group, lactation number, year-season, and wk 1 insulin. The HH produced $10,348 \pm 207 \mathrm{~kg}$ of milk, which was greater than the HJ $(9,129 \pm 230 \mathrm{~kg})$, the JH $(9,384 \pm 190 \mathrm{~kg})$, and the JJ $(7,080 \pm 240 \mathrm{~kg})$. Milk production in lactation 2
\end{abstract}

Received June 29, 2011.

Accepted October 16, 2011.

${ }^{1}$ Corresponding author: guaz@vt.edu
$(9,676 \pm 163 \mathrm{~kg})$ was greater than that in lactation 1 $(8,294 \pm 160 \mathrm{~kg})$. The JJ $(10.3 \pm 4.7 \%)$ had the highest frequency of mastitis. The chance of getting mastitis for $\mathrm{HH}(1.1 \pm 0.9 \%)$ differed from that for HJ (9.4 \pm $4.1 \%)$, JH $(8.1 \pm 3.4 \%)$, and JJ $(10.3 \pm 4.7 \%)$. Genetic group affected hormones and metabolites, which may partially explain differences in reproductive measures and milk yield.

Key words: crossbreeding, reproduction, hormone, metabolite

\section{INTRODUCTION}

The decline in reproductive ability of purebred Holsteins has increased interest in crossbreeding (Heins et al., 2008a). Crossbreeding improves components of milk, fertility, and productive life (VanRaden and Sanders, 2003; Anderson et al., 2007; Heins et al., 2008b). Much of the lower reproductive ability in the Holsteins can be attributed to the state of negative energy balance (NEB) that occurs when they enter lactation after parturition. Factors that influence NEB are precalving body condition, the diet that the animal received before calving, the diet provided postpartum, and genetics. Nonesterified fatty acids, BHBA, insulin, IGF-1, and glucose can be used to describe the state of NEB and its effect on reproduction.

van Knegsel et al. (2007) found that low plasma insulin concentration reduced glucose uptake by muscle and adipose tissue, thus sparing glucose for uptake by the mammary gland, which is not responsive to insulin. During NEB or with low concentrations of insulin, the secretion of hormone-sensitive lipase is stimulated, triggering lipolysis with the subsequent release of NEFA to the bloodstream (Nelson and Cox, 2000; Melendez et al., 2009). According to Staples et al. (1998), insulin concentrations usually reflect energy intake.

Nonesterified fatty acids appear in the bloodstream when the animal breaks down adipose tissue to supply energy needed for milk production. They are taken up by the liver and other tissues and can be oxidized for extra energy supply or esterified into triglycerides. Partial oxidation in the liver can lead to ketosis, and triglyceride formation can lead to fatty liver disorder 
(de Vries and Veerkamp, 2000). Both of these conditions have been related to delayed ovulation, estrus, and pregnancy (Jorritsma et al., 2000). Increased plasma NEFA concentration is a common characteristic in dairy cows during the periparturient period and reflects the increased reliance on adipose tissue reserves to support energy requirements and milk fat synthesis (Pires et al., 2007).

Insulin-like growth factor-1 and insulin enhanced both the proliferation and steroidogenesis of bovine granulosa cells in dose-dependent fashions (Gong, 2002). Insulin and IGF-1 influence ovarian follicular development. Low plasma insulin and IGF-1 concentrations appear linked to differences in reproductive factors such as basal LH concentrations, LH pulse frequency, and subsequent peripheral progesterone concentrations that follow ovulation induced by GnRH. Insulin-like growth factor- 1 is a potent stimulator of progesterone production by bovine luteal cells, and IGF-1 secretion is decreased during NEB. Therefore, IGF-1 holds potential as a hormonal mediator of the effects of energy balance on luteal function (Spicer et al., 1990). Decreased IGF-1 secretion associated with NEB could alter ovarian follicular estradiol production, thereby suppressing the expression of estrus, and cows with high milk production are in NEB and under nutritional stress.

Progesterone (P4) is an indicator of ovarian activity. Ovulation is substantiated by a single plasma sample in which P4 increases above $1 \mathrm{ng} / \mathrm{mL}$ (Harrison et al., 1990; Senatore et al., 1996). Cows reached first estrus on the first of 3 consecutive samples taken twice weekly that had a P4 concentration $>1 \mathrm{ng} / \mathrm{mL}$ (Simmons et al., 1994). Butler et al. (1981) found that average time to first ovulation in multiparous cows was close to 30 d. Negative energy balance may influence reproduction through its direct or indirect influence on $\mathrm{P} 4$ secretion by the corpus luteum (Nebel and McGilliard, 1993). Reestablishment of ovulatory cycles early after parturition guarantees multiple estrous cycles before the breeding period, which influences conception rate (Butler and Smith, 1989).

In addition to metabolite and hormonal changes that occur during early lactation, other factors can affect fertility of dairy cattle. Animals that had retained placenta, nonsystemic metritis, systemic metritis, ovarian cysts, or lameness tended to have lower conception rates and higher days open than healthy animals. Clinical uterine diseases postpartum increase the risk of subclinical endometritis in lactating dairy cows and suppress fertility (Rutigliano et al., 2008), partly because of the decreased fertilization rate (Cerri et al., 2009).

Mastitis remains the costliest disease afflicting the dairy cow. Unfavorable body energy status may lead to elevated SCC and mastitis incidence, thus compromising udder health (Banos et al., 2006). Clinical mastitis may cause a decrease in DMI, swelling of the udder, and in extreme cases, septicemia or endotoxemia, which can lead to death (Bradley, 2002).

Environmental factors such as temperature and photoperiod influence the health and productivity of dairy cows during lactation, possibly via similar physiological effects (do Amaral et al., 2009). Reproduction in dairy cows is extremely sensitive to heat stress (Lucy, 2001). Wolfenson et al. (2000) found that cows with low conception in the summer did not achieve normal fertility until the late fall, long after heat stress had subsided.

The overall objective was to evaluate the physiological differences among genetic groups that might affect reproductive performance of purebred and crossbred dairy cattle from a designed experiment in which cattle were managed the same.

\section{MATERIALS AND METHODS}

\section{Experimental Design}

This study was conducted at the Virginia Tech Dairy Cattle Center (Blacksburg) involving a crossbreeding experiment with the university research herd and Holstein $(\mathbf{H})$ and Jersey $(\mathbf{J})$ breeds. Details of the design are in Olson et al. (2009). The crossbreeding study began at Virginia Tech in the fall of 2002. The design of the study was a diallel model with $\mathrm{H}$ and $\mathrm{J}$ dams as the foundation. These dams were then mated with $4 \mathrm{H}$ bulls and $4 \mathrm{~J}$ bulls, allowing for the creation of $\mathbf{H H}, \mathbf{H J}, \mathbf{J H}$, and $\mathbf{J J}$ genetic groups with the sire listed first and the breed of the dam second. The study included 157 first-lactation cows with $48 \mathrm{HH}, 34 \mathrm{HJ}, 46$ $\mathrm{JH}$, and $29 \mathrm{JJ}$, and 107 second-lactation cows with 35 $\mathrm{HH}, 23 \mathrm{HJ}, 35 \mathrm{JH}$, and $14 \mathrm{JJ}$. Six cows in second lactation were not included in the first-lactation data set. Crossbred project animals were bred to Swedish Red or Brown Swiss bulls, whereas HH and JJ were bred to service sires of their breed. Thus, potential embryonic losses due to inbreeding would affect purebred project animals more than crossbreds.

\section{Blood Collection}

Blood sampling began in 2005 and finished in late 2009. Samples were collected weekly for the first $10 \mathrm{wk}$ after parturition via a coccygeal vessel into two 6-mL $\mathrm{K}_{2}$-EDTA tubes (Fisher, Suwanee, GA). Samples were immediately placed on ice and subsequently centrifuged for $30 \mathrm{~min}$ at $3,000 \times g$ at $4^{\circ} \mathrm{C}$. Plasma was harvested and stored at $-20^{\circ} \mathrm{C}$ until the analysis of P4, NEFA, IGF-1, and insulin. 


\section{Data}

Milk yield, reproductive, and clinical data (mastitis, metritis, ketosis, and displaced abomasum) were collected daily and stored in PCDART (Dairy Records Management Systems, Raleigh, NC). The PCDART information contained pregnancy dates, number of services, types of clinical issues, and information regarding immunization injections.

\section{RIA}

Progesterone concentrations were analyzed by Coat-a-Count kits (Siemens, Los Angeles, CA). The intra- and interassay CV for P4 were 7.4 and $14.5 \%$, respectively. Plasma concentrations of IGF-I were measured as described by Berry et al. (2003); the intra- and interassay CV were 11.3 and $18.3 \%$, respectively. The insulin assay was described previously by Daniels et al. (2008); the intra- and interassay CV were 8.1 and $14.5 \%$, respectively.

\section{NEFA}

Nonesterified fatty acids were analyzed by a colorimetric procedure using reagents and solvents from Wako (Wako Diagnostics/Chemicals Richmond, VA). The intra- and interassay CV were both less than $1 \%$.

\section{Statistical and Data Management}

All data recorded from blood samples were stored in Microsoft Excel (version 2007; Microsoft Corp., Redmond, WA). The data were analyzed using SAS (version 9.2, SAS Institute Inc., Cary, NC). Statistical analyses were conducted using a MIXED procedure with repeated measures, with cow within breed as the repeated variable for each model, chi-square for categorical variables in the FREQUENCY procedure, and the GLIMMIX procedure.

Dependent variables were days open, number of services for pregnancy, P4, NEFA, insulin, IGF-1, clinical condition, and milk yield. Independent variables included $\mathrm{P} 4>1 \mathrm{ng} / \mathrm{mL}$ (described below), genetic group (HH, HJ, JH, and JJ), year-season, lactation number, week of lactation, genetic group by week of lactation, and genetic group by lactation number and lactation number by week of lactation interactions. The variable $\mathrm{P} 4>1 \mathrm{ng} / \mathrm{mL}$ was scored as a yes if a sample for the cow increased $>1 \mathrm{ng} / \mathrm{mL}$ before 30 DIM and no otherwise. Year-season combined the year and the season of calving and accounted for changes in management practices, environmental temperature, and feed quality. Samples were collected over 4 yr, but relatively few calv- ings occurred in 2005 and those were combined with the second year-season. Season was divided into "hot" for the months June to October and "cold" for November to May. The maximum daily temperature was recorded from the Blacksburg National Oceanic and Atmospheric Administration weather station located close $(<0.5$ $\mathrm{km})$ to the Dairy Cattle Center. Maximum daily temperature on the day the sample was taken was included in the model to see how it affected P4, NEFA, insulin, and IGF-1 concentrations. Maximum daily temperature only accounted for the environment effects and was not constrained by hot and cold season definitions, as was the year-season effect. Milk production was actual yield through $305 \mathrm{~d}$ of lactation. For cows not milked a full $305 \mathrm{~d}$, a 305-d yield was calculated by multiplying the last milk recorded from DHI and the days remaining to 305. This approach assumes a flat lactation curve at the end of lactation, which is likely more appropriate for first than for second lactation. Milk yield was not calculated if the lactation was $<280 \mathrm{~d}$; therefore, the maximum extension of any record was $25 \mathrm{~d}$. Analyses used actual milk yield and thus do not reflect energy demands involved in production of fat and protein. A MIXED procedure with repeated measures was used for analysis, with cow within breed as the subject, using the following model for initial analysis:

$$
\begin{aligned}
\mathrm{Y}_{\mathrm{ijk} k m n}= & \mu+\mathrm{B}_{\mathrm{i}}+\mathrm{C}_{(\mathrm{i}) \mathrm{j}}+\mathrm{L}_{\mathrm{k}}+\mathrm{R}_{\mathrm{l}}+\mathrm{b}\left(\mathrm{MT}_{\mathrm{m}}\right)+\mathrm{W}_{\mathrm{n}} \\
& +\mathrm{BL}_{\mathrm{ik}}+\mathrm{BW}_{\mathrm{in}}+\mathrm{LW}_{\mathrm{kn}}+\mathrm{e}_{\mathrm{ijk} \mathrm{knn}},
\end{aligned}
$$

where $Y_{\mathrm{ijklmn}}=$ the dependent variables NEFA, IGF-1, and insulin; $\mu=$ the mean of $\mathrm{Y} ; \mathrm{B}_{\mathrm{i}}=$ fixed effect of genetic group; $\mathrm{C}_{(\mathrm{i}) \mathrm{j}}=$ random effect of cow within genetic group; $L_{k}=$ fixed effect of lactation number; $R_{1}=$ fixed effect of year-season; $\mathrm{b}$ is the linear regression of the response variable on $\mathrm{MT}_{\mathrm{m}}$, the effect of maximum daily temperature; $\mathrm{W}_{\mathrm{n}}$ = fixed effect of week of lactation ( $\mathrm{n}$ $=1$ to 10$) ; \mathrm{BL}_{\mathrm{ik}}=$ interaction of genetic group and lactation number; $\mathrm{BW}_{\text {in }}=$ interaction of genetic group and week of lactation; $\mathrm{LW}_{\mathrm{kn}}=$ interaction of lactation number and the week of lactation; and $\mathrm{e}_{\mathrm{ijklmn}}=$ error assuming one observation per cow per week. All dependent variables were analyzed with models including random cow effects. The independent effects that were significant and that remained in the model describing NEFA were genetic group, lactation number, week of lactation, maximum daily temperature, year-season, genetic group by lactation number, and lactation number by week of lactation interactions. Plasma IGF-1 was described by genetic group, lactation number, week of lactation, maximum daily temperature, year-season, and genetic group by lactation number interaction. The insulin model was described by genetic group, lactation 
number, week of lactation, maximum daily temperature, and year-season. The independent variables describing actual milk yield were genetic group, lactation number, year-season, first-week insulin concentrations, and the genetic group by lactation number interaction.

The GLIMMIX model was used to analyze effects of genetic group and lactation number on increases of $\mathrm{P} 4$ $>1 \mathrm{ng} / \mathrm{mL}$ before 30 DIM; GLIMMIX was also used to determine if the different clinical conditions were affected by genetic group or lactation number. Mastitis, metritis, ketosis, and displaced abomasums were scored as a "yes" if they occurred at least once before 70 DIM and "no" otherwise. Tukey's adjustments were performed on the main effects of genetic group and lactation number to account for multiple 2-way comparisons in the MIXED procedure. Additionally, contrasts were conducted between breed group and lactation number and lactation number and week.

The CORR procedure of SAS was used to evaluate the association among variables that had only 1 observation per cow per lactation (i.e., days open, number of services, milk yield, and DIM) with the wk 1 concentration of NEFA, insulin, and IGF-1. Correlations among NEFA, insulin, and IGF-1 were assessed using all available observations and not just those from wk 1 .

The chi-squared analysis (FREQ) was conducted on the genetic group by $\mathrm{P} 4$ profile frequency to determine if the distribution of profile categories differed by genetic group.

The profile variable classified the way the $\mathrm{P} 4$ concentration increased during the early portion of lactation. Profile consisted of 4 categories based on Petersson et al. (2006): normal, early, short, and delayed. Normal was defined as an increase in plasma $\mathrm{P} 4>1 \mathrm{ng} / \mathrm{mL}$ between d 28 and 30 of lactation that remained elevated above the threshold of $1 \mathrm{ng} / \mathrm{mL}$ for 2 to 3 wk. Early meant the same as normal except P4 increased $>1 \mathrm{ng} /$ $\mathrm{mL}$ before 21 DIM. Short indicated an increase in P4 concentrations $>1 \mathrm{ng} / \mathrm{mL}$ around 28 to 30 DIM followed by a decrease below the threshold level at the next sampling. Delayed profile was assigned to cows that had P4 concentrations that never met threshold levels of $1 \mathrm{ng} / \mathrm{mL}$ before $30 \mathrm{DIM}$ and remained below threshold to 70 DIM.

Dunnett's adjustments were performed on the main effects of genetic group and lactation number to account for the multiple 2-way comparisons in the GLIMMIX procedure. Significance was declared at $P<0.05$.

\section{RESULTS}

\section{Reproductive Results}

Over the 4 yr of sampling, days open ranged from 127 to 169 per year of the study. Genetic groups sig- nificantly affected days open (Table 1). The HH had the greatest days open $(169 \pm 8)$ and they were greater $(P<0.0042)$ than that of HJ $(143 \pm 9)$, JH $(127 \pm$ $8)$, and JJ (132 \pm 10$)$, which did not differ. Days open was positively correlated with number of services per pregnancy $(\mathrm{r}=0.76 ; \mathrm{n}=264 ; P<0.0001)$. Days open was also positively correlated with milk production ( $\mathrm{r}$ $=0.14 ; P<0.03$ ), suggesting that higher producing cows had greater days open. Number of services per pregnancy was significantly affected by genetic group (Table 1). Number of services per pregnancy ranged from 1.9 to 2.4. The $\mathrm{HH}$ had $2.4 \pm 0.1$ services per conception, which was not different from HJ $(2.1 \pm$ $0.2)$ and JJ $(2.1 \pm 0.2)$, but more $(P<0.0458)$ than $\mathrm{JH}(1.9 \pm 0.1)$; HJ, JH, and JJ services per conception were not different.

\section{Progesterone}

The mean initial increase of $\mathrm{P} 4>1 \mathrm{ng} / \mathrm{mL}$ occurred at 3 wk postpartum, suggesting that the first ovulation occurred before this time. Genetic group significantly affected $(P<0.0097)$ the occurrence of $\mathrm{P} 4$ concentrations $>1 \mathrm{ng} / \mathrm{mL}$ in the first 30 DIM. The HH had 42.2 $\pm 5.4 \%$ of cows with $\mathrm{P} 4$ concentrations increasing $>1$ $\mathrm{ng} / \mathrm{mL}$ in the first $30 \mathrm{DIM}$ compared with $43.9 \pm 6.6 \%$ of HJ, $61.7 \pm 5.4 \%$ of $\mathrm{JH}$, and $67.4 \pm 7.2 \%$ of JJ. Genetic group differences were between $\mathrm{HH}$ and JJ ( $P$ $<0.0427)$.

\section{NEFA}

The NEFA concentrations at wk 1 were positively correlated with milk production $(\mathrm{r}=0.17 ; P<0.01)$ and negatively correlated with DIM when samples were collected $(\mathrm{r}=-0.40 ; \mathrm{n}=264 ; P<0.0001)$, IGF-1 $(\mathrm{r}=$ $-0.10 ; \mathrm{n}=2,632 ; P<0.0001)$, and insulin concentrations $(\mathrm{r}=-0.31 ; \mathrm{n}=2,632 ; P<0.0001)$. Lactation number, week of lactation, year-season, and genetic group by lactation number and lactation number by week of lactation interactions significantly affected

Table 1. Reproductive measures $( \pm \mathrm{SE})$ for the purebred Holstein $(\mathrm{HH})$ and Jersey (JJ), and crossbred Holstein-Jersey (HJ) and JerseyHolstein $(\mathrm{JH})$ cattle

\begin{tabular}{lccc}
\hline $\begin{array}{l}\text { Genetic } \\
\text { group }\end{array}$ & $\begin{array}{c}\text { Days } \\
\text { open }^{1}\end{array}$ & $\begin{array}{c}\text { No. of } \\
\text { services }^{2}\end{array}$ & $\begin{array}{c}\text { Progesterone }>1 \mathrm{ng} / \mathrm{mL} \\
\text { by } 30 \operatorname{DIM}^{3}(\%)\end{array}$ \\
\hline HH & $169 \pm 8^{\mathrm{a}}$ & $2.4 \pm 0.1^{\mathrm{a}}$ & $42.2 \pm 5.4^{\mathrm{a}}$ \\
HJ & $143 \pm 9^{\mathrm{b}}$ & $2.1 \pm 0.2^{\mathrm{ab}}$ & $43.9 \pm 6.6^{\mathrm{ab}}$ \\
JH & $127 \pm 8^{\mathrm{b}}$ & $1.9 \pm 0.1^{\mathrm{b}}$ & $61.7 \pm 5.4^{\mathrm{ab}}$ \\
JJ & $132 \pm 10^{\mathrm{b}}$ & $2.1 \pm 0.2^{\mathrm{ab}}$ & $67.4 \pm 7.2^{\mathrm{b}}$ \\
\hline
\end{tabular}

${ }^{1}$ Different superscripts differ at overall $P<0.042$.

${ }^{2}$ Different superscripts differ at overall $P<0.0458$.

${ }^{3}$ Different superscripts differ at overall $P<0.0427$. 
NEFA concentrations. The NEFA concentrations were higher $(P<0.0002)$ in second lactation $(0.52 \pm 0.02$ $\mathrm{mEq} / \mathrm{L})$ compared with first lactation $(0.45 \pm 0.02$ $\mathrm{mEq} / \mathrm{L}$ ). The NEFA concentration was highest at wk 1 and gradually decreased over the first $10 \mathrm{wk}$ of lactation (Figure 1). The NEFA concentrations were highest $(P<0.0001)$ in the cold season in 2005-2006, 2007, and 2009, whereas they were highest in the hot season in 2008. The NEFA concentrations gradually declined over the first $10 \mathrm{wk}$ in both lactations (lactation number by week of lactation effect; $P<0.0058$ ), but secondlactation NEFA concentration was higher initially than that in first lactation (Figure 1). Significant differences were found between first-and second-lactation NEFA at wk 1, 2, 4, and 5. The interaction between genetic group and lactation number showed that all genetic groups had higher NEFA concentrations in second lactation $(P<0.0114)$ compared with first. The $\mathrm{HH}$ in second lactation were significantly different from the $\mathrm{JH}$ in second lactation $(P<0.0039$; Figure 2$)$.

\section{Insulin}

Insulin was positively correlated with DIM $(\mathrm{r}=0.08$; $\mathrm{n}=264 ; P<0.0001)$ and IGF-1 concentrations $(\mathrm{r}=$ $0.12 ; \mathrm{n}=2,631 ; P<0.0001)$. Insulin was negatively correlated with milk production $(\mathrm{r}=-0.28 ; \mathrm{n}=217$; $P<0.0001)$. Genetic group, lactation number, week of lactation, maximum daily temperature, and year-season affected insulin concentrations. The insulin concentrations ranged from 0.66 to $0.87 \mathrm{ng} / \mathrm{mL}$. The significant genetic group differences were because the HJ had the greatest $(P<0.0007)$ insulin concentrations $(0.87 \pm$ $0.04 \mathrm{ng} / \mathrm{mL})$ and the JJ had the lowest $(0.66 \pm 0.04$ $\mathrm{ng} / \mathrm{mL})$, but insulin in $\mathrm{HH}(0.83 \pm 0.03 \mathrm{ng} / \mathrm{mL})$ and HJ was different from insulin in JJ. The insulin concentration in $\mathrm{JH}$ was $0.76 \pm 0.03 \mathrm{ng} / \mathrm{mL}$ and not different from that of the other genetic groups. Significant differences were found in insulin concentrations $(P<0.0066)$ in first lactation $(0.81 \pm 0.03 \mathrm{ng} / \mathrm{mL})$ compared with second lactation $(0.72 \pm 0.03 \mathrm{ng} / \mathrm{mL})$. Over the first 10 wk of lactation, insulin concentrations started out high, decreased in wk 2, and then gradually increased (Figure 3). Insulin concentrations were highest in the hot season $(P<0.0001)$ compared with the cold season during 2005-2006 and 2007 but were higher in the cold season compared with the hot season in 2008 and 2009 .

\section{IGF-1}

Concentrations of IGF-1 were positively correlated with DIM ( $\mathrm{r}=0.11 ; \mathrm{n}=261 ; P<0.0001)$ and insulin concentrations $(\mathrm{r}=0.12 ; P<0.0001)$. Week of lactation, year-season, maximum daily temperature, and



Figure 1. The temporal change in NEFA concentrations (LSM \pm $\mathrm{SE})$ during the first $10 \mathrm{wk}$ of lactation across all genetic groups. The week effect was significant at $P<0.0001$. The interaction between NEFA concentrations in the first 10 wk of lactation for first and second lactation $(P<0.0058)$. The slice analysis revealed a significant change between lactations at wk $1(P<0.0002), 2(P<0.004), 4(P$ $<0.0001)$, and $5(P<0.007)$.

genetic group by lactation number interaction affected IGF-1 concentrations; the average IGF-1 concentration was $80.0 \pm 66.8 \mathrm{ng} / \mathrm{mL}$. The IGF-1 concentrations gradually increased $(P<0.0001)$ over the first $10 \mathrm{wk}$ of lactation (Figure 4). The IGF-1 concentrations were similar in both the hot season and cold season in 20052006. In 2007, the IGF-1 concentrations were greater in the cold season compared with the hot season. In 2008 and 2009, the IGF-1 concentrations were greater in the hot season compared with the cold season. The $\mathrm{HH}$ had higher IGF-1 concentrations in first lactation

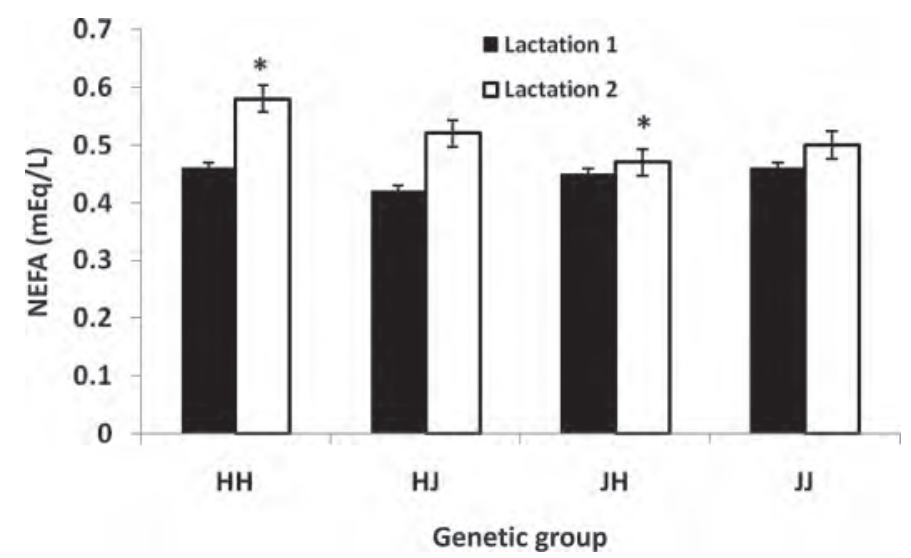

Figure 2. The genetic group NEFA concentrations (LSM \pm SE) by lactation number interaction $(P<0.01)$. The contrasts revealed that the difference occurs between the $\mathrm{HH}$ in second lactation compared with the $\mathrm{JH}$ in second lactation $(P<0.004)$. HH $=$ Holstein, HJ $=$ Holstein-Jersey cross, JH = Jersey-Holstein cross, JJ = Jersey. 


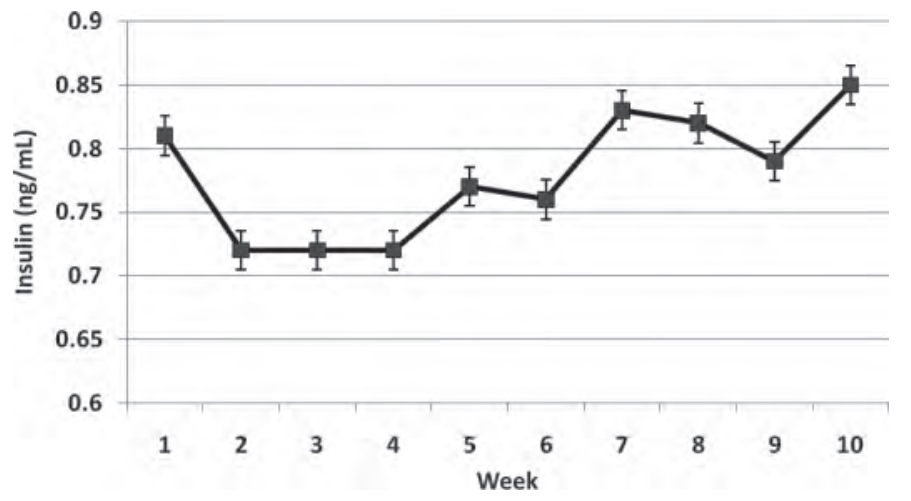

Figure 3. The temporal change in insulin concentrations of all genetic groups $(\mathrm{LSM} \pm \mathrm{SE})$ over the first $10 \mathrm{wk}$ of lactation $(P<$ $0.0001)$.

compared with second lactation $(P<0.0018)$. The HJ had higher IGF-1 concentrations in second lactation compared with first lactation. The $\mathrm{JH}$ were similar to $\mathrm{HH}$ in that they had higher IGF-1 concentrations in first lactation compared with second lactation. The JJ had the same IGF-1 concentrations in both first and second lactations (Figure 5).

\section{Milk}

Milk production was positively correlated with lactation number $(\mathrm{r}=0.44 ; \mathrm{n}=241 ; P<0.0001)$ and days open in the current lactation $(\mathrm{r}=0.14 ; P<0.03)$. Milk production was negatively correlated with insulin concentrations $(\mathrm{r}=-0.28 ; \mathrm{n}=217 ; P<0.0001)$. Actual 305-d milk production was affected by genetic group, lactation number, year-season, and first week insulin concentrations. The genetic group by lactation number interaction was not significant $(P<0.3813)$. The HH cows produced the greatest milk yield in both first and second lactations and the JJ had the lowest in both lactations. The JH came closest to the $\mathrm{HH}$ in actual

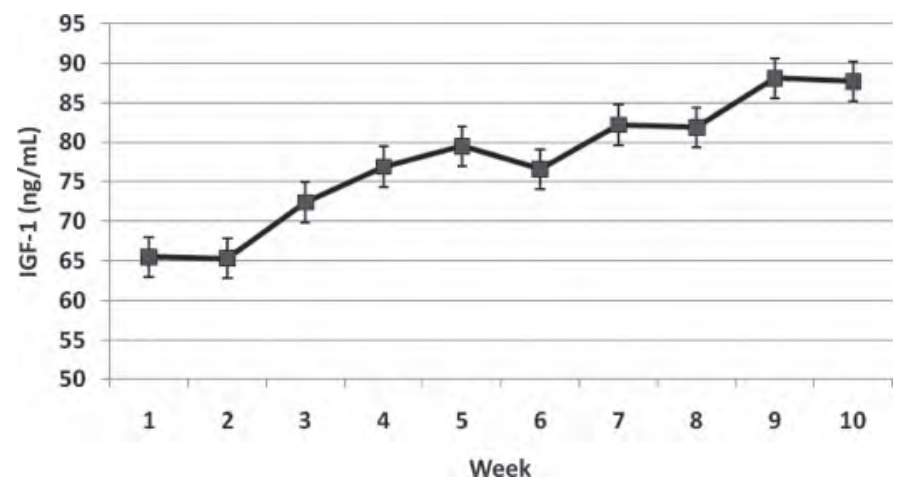

Figure 4. The temporal change in IGF-1 concentrations (LSM \pm $\mathrm{SE})$ of all genetic groups over the first $10 \mathrm{wk}$ of lactation $(P<0.0001)$.

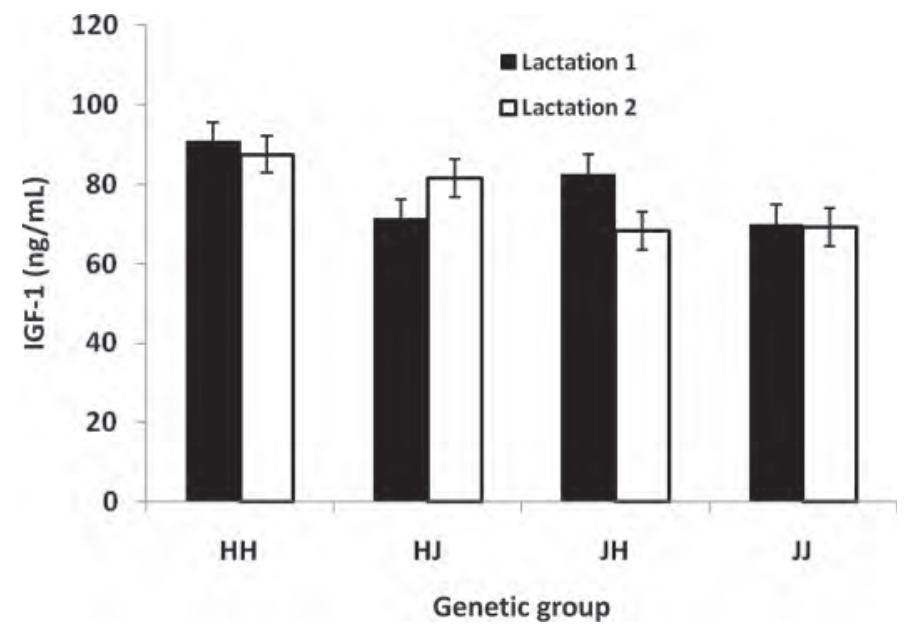

Figure 5. Genetic group IGF-1 concentrations (LSM \pm SE) by lactation number interaction. The overall interaction between genetic group and lactation number was significant $(P<0.0018)$. No contrasts between genetic groups and their lactations were found. $\mathrm{HH}=$ Holstein, HJ = Holstein-Jersey cross, JH = Jersey-Holstein cross, JJ $=$ Jersey.

305-d milk yield: $\mathrm{HH}$ had $10,348 \mathrm{~kg}$ and the $\mathrm{JH}$ had $9,384 \mathrm{~kg}$. The HH were different from HJ, JH, and JJ, and the HJ and JH were different from the JJ (Table $2)$. Milk production was greater $(P<0.0001)$ in second lactation $(9,676 \pm 163 \mathrm{~kg})$ compared with first lactation $(8,294 \pm 160 \mathrm{~kg})$.

\section{Clinical Conditions}

Only clinical condition of mastitis differed by genetic group and lactation number. Only clinical conditions that occurred within the first 70 DIM, the period in which blood samples were collected, were recorded. Mastitis was significantly different by genetic group $(P$ $<0.0344)$ and lactation number $(P<0.0006$; Table $3)$. The JJ $(10.3 \pm 4.7 \%)$ had the highest frequency of mastitis. The chance of getting mastitis for $\mathrm{HH}$ (1.1 $\pm 0.9 \%)$ differed from that for HJ $(9.4 \pm 4.1 \%)$, JH

Table 2. Genetic group least squares means $( \pm \mathrm{SE})$ of milk production (actual milk in first $305 \mathrm{~d}$ of lactation) in first and second lactation in purebred Holstein $(\mathrm{HH})$ and Jersey (JJ) cattle and crossbred HolsteinJersey (HJ) and Jersey-Holstein (JH) cattle ${ }^{1}$

\begin{tabular}{lcc}
\hline $\begin{array}{l}\text { Genetic } \\
\text { group }\end{array}$ & $\begin{array}{c}\text { Milk } \\
(\mathrm{kg})\end{array}$ & $\mathrm{SE}$ \\
\hline HH & $10,348^{\mathrm{a}}$ & 207.2 \\
HJ & $9,129^{\mathrm{b}}$ & 229.8 \\
JH & $9,384^{\mathrm{b}}$ & 189.6 \\
JJ & $7,080^{\mathrm{c}}$ & 239.8 \\
\hline
\end{tabular}

Overall genetic group effect $P<0.0001$; ${ }^{\text {ab }} P<0.0001$ (HH vs. HJ) $P$ $<0.0020$ (HH vs. JH) $P<0.0001$ (HH vs. JJ); ${ }^{\text {bc }} P<0.0001$ (HJ vs. JJ) $P<0.0001$ (JH vs. JJ). 
$(8.1 \pm 3.4 \%)$, and JJ. A greater frequency of mastitis $(P<0.0006)$ was observed in first-lactation cows $(17.6$ $\pm 3.6 \%)$ compared with second-lactation cows $(1.6 \pm$ $1.1 \%)$. The $\mathrm{HH}$ had a $16.9 \pm 4.2 \%$ incidence of metritis. The incidences of ketosis or displaced abomasum did not differ among genetic groups or lactation number. However, the $\mathrm{HH}$ had an incidence of ketosis of $11 \pm$ $3.5 \%$, and the occurrence of displaced abomasum in $\mathrm{HH}$ was $14.5 \pm 3.9 \%$. Overall means for all dependent variables for each genetic group and lactation number are shown in Table 3.

\section{DISCUSSION}

We chose not to combine the reciprocal crosses into a single crossbred group because one intent of the project design was to compare reciprocal crosses. Project animals sired by Holstein bulls had inferior reproductive performance compared with animals sired by Jersey bulls, although statistically significant differences did not always support this observation. The samples of foundation bulls used could account for this result. The $\mathrm{HH}$ had the highest service number per pregnancy (2.4) followed by the HJ (2.1), JJ (2.1), and finally the JH (1.9). The days open analysis followed the same pattern, with the HH (169) having the highest days open, then the HJ (143), JJ (132), and finally the JH (127). The HJ appear to be better reproductively than the HH and the JH were better than the JJ. The correlations regarding these 2 variables agree. Service number per pregnancy was correlated with days open $(\mathrm{r}=0.76)$. More attempts at AI per pregnancy increased days open. Recent research has suggested that a 2- to 3-wk advantage of days open exists for crossbreds compared with purebred Holsteins, which would enhance the profitability of dairy production systems (Dechow et al., 2007; Heins et al., 2008a). McDowell (1982) showed that the crossbreds averaged 3 to $17 \%$ fewer days open compared with the purebreds at 3 locations. The current data at Virginia Tech supports this, with the HJ $(143 \mathrm{~d})$ and $\mathrm{JH}(127 \mathrm{~d})$ having fewer days open than the HH (169 d); the JJ (132 d) did not differ from HJ and $\mathrm{JH}$.

The genetic groups differed in the analysis of $\mathrm{P} 4$. The $\mathrm{HH}$ and $\mathrm{HJ}$ cows had a higher incidence of a delayed $\mathrm{P} 4$ secretion; that is, a lower percentage of cows achieving $>1 \mathrm{ng} / \mathrm{mL}$ P 4 by 30 DIM. Around $60 \%$ of these cows were in the "delayed" P4 category, unlike the $\mathrm{JH}$ and $\mathrm{JJ}$, in which only $30 \%$ of these animals were delayed. Petersson et al. (2006) found that cows with atypical $\mathrm{P} 4$ profiles in the previous lactation were at high risk of displaying the same profile in subsequent lactations. That most Holstein-sired cows were in the delayed category suggests that the majority of the $\mathrm{HH}$ and $\mathrm{HJ}$ cows were compromised and did not resume cycling until after 30 DIM. Cows with successful pregnancies had higher concentrations of $\mathrm{P} 4$ in the cycle before breeding compared with cows with low P4 concentrations (Shrestha et al., 2004). Therefore, the finding of the majority of the $\mathrm{HH}$ and HJ falling into the delayed P4 profile may explain the fewer successful pregnancies compared with the JH and JJ. This finding supports Shrestha et al. (2004), who found that cows with abnormal ovarian cycles, including prolonged luteal phase and anovulation, during the preservice period had a reduced reproductive performance compared with those cows that experienced normal ovarian cycles.

Concentrations of NEFA were higher in second lactation for all genetic groups compared with first lactation and gradually declined over time as cows consumed

Table 3. Clinical condition percentages $( \pm \mathrm{SE})$ for the first $10 \mathrm{wk}$ after parturition in first and second lactation in purebred Holstein (HH) and Jersey (JJ), and crossbred Holstein-Jersey (HJ) and Jersey-Holstein (JH) cattle $^{1}$

\begin{tabular}{|c|c|c|c|c|}
\hline \multirow[b]{2}{*}{ Item } & \multicolumn{4}{|c|}{ Clinical condition (\%) } \\
\hline & Mastitis & Metritis & Ketosis & $\begin{array}{c}\text { Displaced } \\
\text { abomasum }\end{array}$ \\
\hline \multicolumn{5}{|c|}{ Genetic group } \\
\hline $\mathrm{HH}$ & $1.1 \pm 0.9^{\mathrm{a}}$ & $16.9 \pm 4.2$ & $11.0 \pm 3.5$ & $14.5 \pm 3.9$ \\
\hline HJ & $9.4 \pm 4.1^{\mathrm{b}}$ & $4.8 \pm 2.7$ & $10.8 \pm 4.2$ & $7.1 \pm 3.4$ \\
\hline $\mathrm{JH}$ & $8.1 \pm 3.4^{\mathrm{b}}$ & $6.8 \pm 2.8$ & $8.7 \pm 3.1$ & $7.4 \pm 2.9$ \\
\hline JJ & $10.3 \pm 4.7^{\mathrm{b}}$ & $0.0 \pm 0.01$ & $9.9 \pm 4.7$ & $2.4 \pm 2.3$ \\
\hline \multicolumn{5}{|c|}{ Lactation no. } \\
\hline 1 & $17.6 \pm 3.6^{\mathrm{c}}$ & $0.4 \pm 0.4$ & $7.6 \pm 2.1$ & $6.4 \pm 2.2$ \\
\hline 2 & $1.6 \pm 1.1^{\mathrm{d}}$ & $0.2 \pm 0.2$ & $13.1 \pm 3.4$ & $6.9 \pm 2.6$ \\
\hline
\end{tabular}

Overall genetic group effect for mastitis: $P<0.0344$ and overall lactation effect for mastitis $P<0.0006$; ${ }^{\text {ab }} P<$ 0.0322 (HH vs. HJ); $P<0.0488$ (HH vs. JH) $P<0.0256$ (HH vs. JJ). The crossbreds were not different from each other or from the purebred JJ; ${ }^{\text {cd }} P<0.0006$. Overall genetic group effect for metritis was $P<0.0817$; there were 24 observations of metritis in the study. No significant genetic group or lactation effects were found for ketosis and displaced abomasums. 
more of the energy needed for all of their activities. This supports Doepel et al. (2002), who found that NEFA concentrations decreased as DMI increased after calving. The NEFA are formed in early lactation because the cow is not consuming the amount of feed required to meet all of her energy demands (Roche et al., 2009). The HH $(0.52 \mathrm{mEq} / \mathrm{L})$ had the highest average NEFA concentration compared with the other genetic groups, supporting Oikonomou et al. (2008), who found that estimated genetic variance of serum NEFA was different from zero until wk 24 of lactation. This could explain why the $\mathrm{HH}$ resume cycling later in lactation. The NEFA concentrations were lower in the hot season compared with the cold, except in 2008, when the NEFA concentration was higher in the cold season than the hot. Causes of the interaction could include management protocols or feed quality. The nutritional environment needs to be sufficient so the lactating dairy cow can meet her energy demands from DMI, thus reducing tissue mobilization (Roche et al., 2009).

Insulin concentrations started high $(0.81 \mathrm{ng} / \mathrm{mL})$, decreased in the second week $(0.72 \mathrm{ng} / \mathrm{mL})$, and then gradually increased throughout the rest of early lactation. This finding supports Doepel and colleagues (2002), who found insulin concentrations to be low during early postpartum. The cows in the study had insulin concentrations above that of the starting week at wk 7,8 , and 10 of lactation. In addition, our results agreed with those of Tanaka et al. (2008) in that the insulin concentrations decreased from wk 1 to wk 2 . Insulin concentrations were lower in second lactation than first lactation ( 0.72 vs. $0.81 \mathrm{ng} / \mathrm{mL})$, which could be attributed to dairy cows producing more milk in second lactation $(\mathrm{r}=-0.28)$, which may be associated with insulin resistance (Chagas et al., 2009). Our results support this concept because our cows had significantly lower insulin concentrations in second lactation compared with first lactation. Hypo-insulinemia and reduced insulin responsiveness of skeletal muscle and adipose tissue occur concurrently in early lactation (Bell and Bauman, 1997).

The IGF-1 concentrations were low during the first week of sampling $(65.5 \mathrm{ng} / \mathrm{mL})$ and gradually increased as the lactation progressed. This is consistent with the findings of Ferguson (2005), in which IGF-1 activity in the blood decreased in lactating cows with high milk production. The JH had lower IGF-1 concentrations in second lactation $(68.3 \mathrm{ng} / \mathrm{mL})$ than $\mathrm{HH}$ in first lactation $(90.3 \mathrm{ng} / \mathrm{mL})$, which could reflect different nutrient restrictions. Overall, second-lactation animals had lower IGF-1 concentrations $(76.8 \mathrm{ng} / \mathrm{mL})$ compared with first-lactation animals $(78.1 \mathrm{ng} / \mathrm{mL})$. This could be because the cows in second lactation were under more lactation stress than those in first lactation. Spicer et al. (1990) reported that IGF-1 secretion decreased during a NEB state. The NEB could also explain why the IGF-1 concentrations were low. Plasma IGF-1 is an essential hormone that links nutrition with growth. Plasma IGF-1 decreases with nutrient restriction and is connected with interference with normal ovarian cycling and inhibition of folliculogenesis and ovulation (Ferguson, 2005). The decreased IGF-1 concentrations could be associated with the NEB of the cows in early lactation, which could prevent the cows returning to estrus. According to Spicer et al. (1990), decreased IGF-1 secretion caused by NEB could alter ovarian follicular estradiol production, thereby suppressing the expression of estrus. In addition, IGF-1 concentrations in the blood appear to be influenced by the nutritional status of the cow, and the cows with higher milk production undergo greater nutritional stress. According to Zulu et al. (2002), plasma IGF-1 concentrations are directly related to energy balance, and IGF-1 was cited as a potential hormone mediator or nutritional control of fertility.

The actual 305-d milk yield was highest in the $\mathrm{HH}$ $(10,348 \mathrm{~kg})$ followed by the $\mathrm{JH}(9,384 \mathrm{~kg})$, HJ $(9,129$ $\mathrm{kg})$, and JJ (7,080 kg). The actual 305-d milk yield does not account for energy in fat and protein. The actual milk yield could be an indicator of why the $\mathrm{HH}$ genetic group did not resume cycling before 30 DIM. Milk production was higher in second lactation $(9,676 \mathrm{~kg})$ compared with first lactation $(8,295 \mathrm{~kg})$ across all genetic groups, which could explain why IGF-1 concentrations were lower and NEFA concentrations higher in second lactation compared with first lactation. Garmo et al. (2009) found that the level of milk production had the greatest negative effect on reproductive performance, suggesting that reduced fertility is caused by the inability to meet the nutritional requirements. Clearance of reproductive hormones may be involved because Turino et al. (2010) reported faster pharmacokinetic profiles in high-compared with low-producing dairy cows. The HH had the highest milk production and decreased reproductive performance, supporting Lucy et al. (1992), who found that NEB was associated with reduced expression of estrus and lessened responses to procedures for synchronization of estrus. This may be due to the inconsistent growth and development of ovarian follicles.

Clinical conditions varied among genetic groups and lactation number. Significance of group differences was limited by the low frequency of some classes in binomial analyses. Mastitis occurred more frequently in JJ (10.3\%), HJ (9.4\%), and JH (8.1\%) compared with $\mathrm{HH}$ $(1.1 \%)$, and more frequently in first lactation (17.6\%) compared with second lactation (1.6\%). Mastitis results 
in this 2-yr study support those of Olson et al. (2011), who found that $\mathrm{HH}$ had the lowest incidence of mastitis in first lactation using many of the same animals. The transition period is a high-risk time for cows developing mastitis (Chagunda et al., 2006). Cows having one or more reproductive, nutritional, or health-related issues before 30 DIM consume less feed during the periparturient period (Zamet et al., 1979). Cows with metabolic disturbances or health problems occurring during early lactation produce less milk than healthy cows, resulting in economic losses for dairy farmers (Drackley, 1999). Cows in a severe NEB state during the transition period are characterized by increased circulating NEFA concentrations, which may lead to suppression of the immune system (Lacetera et al., 2004; Contreras et al., 2010). Therefore, cows exhibiting a severe NEB during the transition period may be more susceptible to mastitis than those cows experiencing a moderate NEB. The NEFA concentrations were highest for the $\mathrm{HH}$ in second lactation. However, in our study, the HJ, JH, and JJ had the higher incidence of mastitis. However, other breed factors may be involved with the relationship between NEB and mastitis as we have evidence of deeper udders on the HJ, JH, and, to a lesser extent, JJ animals (data not shown), supporting Heins et al. (2008b). Severe NEB and deeper udders lead to a greater chance for mastitis.

\section{CONCLUSIONS}

The JH crossbreds had more efficient reproductive performance compared with either of the purebred half sisters at Virginia Tech. The JH had fewer days open and required fewer services per conception than the HH, HJ, or JJ. The JH group produced more milk than the JJ or the HJ, but not more than the HH. A potential sire effect might have allowed the JJ and JH cows to return to cycling in the first 30 DIM; however, only $4 \mathrm{JJ}$ sires and $4 \mathrm{HH}$ sires were used in the study. Milk production and NEFA concentrations were higher in second lactation and IGF-I concentrations were lower. These 3 components together could characterize why cows take longer to come back into estrus. Further studies should look at the external factors more closely to see how they affect cows. In addition, the relative influence of sire versus dam breed needs further examination.

\section{ACKNOWLEDGMENTS}

The authors acknowledge the contributions of Sarah Sheer (Department of Dairy Science, Virginia Tech, Blacksburg) in performing progesterone assays.

\section{REFERENCES}

Anderson, T., R. Shaver, P. Bosma, and V. De Boer. 2007. Case study: Performance of lactating Jersey and Jersey-Holstein crossbred verses Holstein cows in a Wisconsin confinement dairy herd. Prof. Anim. Sci. 23:541-545.

Banos, G. S., M. P. Coffey, E. Wall, and S. Brotherstone. 2006. Genetic relationship between first-lactation body energy and later-life udder health in dairy cattle. J. Dairy Sci. 89:2222-2232.

Bell, A. W., and D. E. Bauman. 1997. Adaptations of glucose metabolism during pregnancy and lactation. J. Mammary Gland Biol. Neoplasia 2:265-278.

Berry, S. D., P. M. Jobst, S. E. Ellis, R. D. Howard, A. V. Capuco, and R. M. Akers. 2003. Mammary epithelial proliferation estrogen receptor alpha expression in prepubertal heifers: Effects of ovariectomy and growth hormone. J. Dairy Sci. 86:2098-2105.

Bradley, A. 2002. Bovine mastitis: An evolving disease. Vet. J. 164:116-128.

Butler, W. R., R. W. Everett, and C. E. Coppock. 1981. The relationships between energy balance, milk production and ovulation in postpartum Holstein cows. J. Anim. Sci. 53:742-748.

Butler, W. R., and R. D. Smith. 1989. Interrelationships between energy balance and postpartum reproductive function in dairy cattle. J. Dairy Sci. 72:767-783.

Cerri, R. L. A., H. M. Rutigliano, F. S. Lima, D. B. Araujo, and J. E. P. Santos. 2009. Effect of source of supplemental selenium on uterine health and embryo quality in high-producing dairy cows. Theriogenology 71:1127-1137.

Chagas, L. M., M. C. Lucy, P. J. Back, D. Blache, J. M. Lee, P. J. S. Gore, A. J. Sheahan, and J. R. Roche. 2009. Insulin resistance in divergent strains of Holstein-Friesian dairy cows offered fresh pasture and increasing amounts of concentrate in early lactation. J. Dairy Sci. 92:216-222.

Chagunda, M. G. G., T. Larsen, M. Bjerring, and K. L. Ingvartsen. 2006. L-Lactate dehydrogenase and $N$-acetyl- $\beta$-D-glucosaminidase activities in bovine milk as indicators of non-specific mastitis. J. Dairy Res. 73:431-440.

Contreras, G. A., N. J. O'Boyle, T. H. Herdt, and L. M. Sordillo. 2010. Lipomobilization in periparturient dairy cows influences the composition of plasma nonesterified fatty acids and leukocyte phospholipid fatty acids. J. Dairy Sci. 93:2508-2516.

Daniels, K. M., S. R. Hill, K. F. Knowlton, R. E. James, M. L. McGilliard, and R. M. Akers. 2008. Effects of milk replacer composition on selected blood metabolites and hormones in preweaned Holstein heifers. J. Dairy Sci. 91:2628-2640.

de Vries, M. J., and R. F. Veerkamp. 2000. Energy balance of dairy cattle in relation to milk production variables and fertility. J. Dairy Sci. 83:62-69.

Dechow, C. D., G. W. Rogers, J. B. Cooper, M. I. Phelps, and A. L. Mosholder. 2007. Milk, fat, protein, somatic cell score, and days open among Holstein, Brown Swiss, and their crosses. J. Dairy Sci. 90:3542-3549.

do Amaral, B. C., E. E. Connor, S. Tao, J. Hayen, J. Bubolz, and G. E. Dahl. 2009. Heat-stress abatement during the dry period: Does cooling improve transition into lactation? J. Dairy Sci. 92:59885999 .

Doepel, L., H. Lapierre, and J. J. Kennelly. 2002. Peripartum performance and metabolism of dairy cows in response to prepartum energy and protein intake. J. Dairy Sci. 85:2315-2334.

Drackley, J. K. 1999. Biology of dairy cows during the transition period: The final frontier? J. Dairy Sci. 82:2259-2273.

Ferguson, J. D. 2005. Nutrition and reproduction in dairy herds. Vet. Clin. North Am. Food Anim. Pract. 21:325-347.

Garmo, R. T., E. Ropstad, Ø. Havrevoll, E. Thuen, H. Steinshamn, A. Waldmann, and O. Reksen. 2009. Commencement of luteal activity in three different selection lines for milk yield and fertility in Norwegian Red cows. J. Dairy Sci. 92:2159-2165.

Gong, J. G. 2002. Influence of metabolic hormones and nutrition on ovarian follicle development in cattle: Practical implications. Domest. Anim. Endocrinol. 23:229-241. 
Harrison, R. O., S. P. Ford, J. W. Young, A. J. Conley, and A. E. Freeman. 1990. Increased milk production versus reproductive and energy status of high producing dairy cows. J. Dairy Sci. 73:2749-2758

Heins, B. J., L. B. Hansen, A. J. Seykora, A. R. Hazel, D. G. Johnson, and J. G. Linn. 2008a. Crossbreds of Jersey $\times$ Holstein compared with purebred Holsteins for body weight, body condition score, dry matter intake, and feed efficiency during the first one hundred fifty days of first lactation. J. Dairy Sci. 91:3716-3722.

Heins, B. J., L. B. Hansen, A. J. Seykora, D. G. Johnson, J. G. Linn, L. E. Romano, and A. R. Hazel. 2008b. Crossbreds of Jersey $\times$ Holstein compared to purebred Holsteins for production, fertility, and body and udder measurements during first lactation. J. Dairy Sci. 91:1270-1278.

Jorritsma, R., H. Jorritsma, Y. H. Schukken, and G. H. Wentink. 2000. Relationships between fatty liver and fertility and some periparturient diseases in commercial Dutch dairy herds. Theriogenology 54:1065-1074.

Lacetera, N., D. Scalia, O. Franci, U. Bernabucci, B. Ronchi, and A. Nardone. 2004. Effects of nonesterified fatty acids on lymphocyte function in dairy heifers. J. Dairy Sci. 87:1012-1014.

Lucy, M. C. 2001. Reproduction loss in high-producing dairy cattle: Where will it end? J. Dairy Sci. 84:1277-1293.

Lucy, M. C., C. R. Staples, W. W. Thatcher, P. S. Erickson, R. M. Cleale, J. L. Firkins, J. H. Clark, M. R. Murphy, and B. O. Brodie. 1992. Influence of diet composition, dry-matter intake, milk production and energy balance on time of post-partum ovulation and fertility in dairy cows. Anim. Prod. 54:323-331.

McDowell, R. E. 1982. Crossbreeding as a system of mating for dairy production. Southern Cooperative Series Bulletin No. 259. Louisiana Agricultural Experiment Station, Baton Rouge.

Melendez, P., M. P. Marin, J. Robles, C. Rios, M. Duchens, and L. Archbald. 2009. Relationship between serum nonesterified fatty acids at calving and the incidence of periparturient diseases in Holstein dairy cows. Theriogenology 72:826-833.

Nebel, R. L., and M. L. McGilliard. 1993. Interactions of high milk yield and reproductive performance in dairy cows. J. Dairy Sci. $76: 3257-3268$.

Nelson, D. L., and M. M. Cox. 2000. Integration and hormonal regulation of mammalian metabolism. Pages 869-901 in Lehninger Principles of Biochemistry. 3rd ed. D. L. Nelson, and M. M. Cox, ed. Worth Publishers, New York, NY.

Oikonomou, G., G. E. Valergakis, G. Arsenos, N. Roubies, and G. Banos. 2008. Genetic profile of body energy and blood metabolic traits across lactation in primiparous Holstein cows. J. Dairy Sci. 91:2814-2822.

Olson, K. M., B. G. Cassell, M. D. Hanigan, and R. E. Pearson. 2011. Short communication: Interaction of energy balance, feed efficiency, early lactation health events, and fertility in first-lactation Holstein, Jersey, and reciprocal F1 crossbred cows. J. Dairy Sci. 94:507-511.

Olson, K. M., B. G. Cassell, A. J. McAllister, and S. P. Washburn. 2009. Dystocia, stillbirth, gestation length, and birth weight in Holstein, Jersey, and reciprocal crosses from a planned experiment. J. Dairy Sci. 92:6167-6175.

Petersson, K. J., H. Gustafsson, E. Strandberg, and B. Berglund. 2006. Atypical progesterone profiles and fertility in Swedish dairy cows. J. Dairy Sci. 89:2529-2538.
Pires, J. A. A., J. B. Pescara, and R. R. Grummer. 2007. Reduction of plasma NEFA concentrations by nicotinic acid enhances the response to insulin in feed-restricted Holstein cows. J. Dairy Sci. 90:4635-4642.

Roche, J. R., N. C. Friggens, J. K. Kay, M. W. Fisher, K. J. Stafford, and D. P. Berry. 2009. Invited review: Body condition score and its association with dairy cow productivity, health, and welfare. J. Dairy Sci. 92:5769-5801.

Rutigliano, H. M., F. S. Lima, R. L. A. Cerri, L. F. Greco, J. M. Vilela, V. Magalhães, F. T. Silvestre, W. W. Thatcher, and J. E. P. Santos. 2008. Effects of method presynchronization and source of Selenium on uterine health and reproduction in dairy cows. J. Dairy Sci. 91:3323-3336.

Senatore, E. M., W. R. Butler, and P. A. Oltenacu. 1996. Relationships between energy balance and postpartum ovarian activity and fertility in first lactation dairy cows. J. Anim. Sci. 62:17-23.

Shrestha, H. K., T. Nakao, T. Suzuki, T. Higaki, and M. Akita. 2004. Effects of abnormal ovarian cycles during pre-service period postpartum on subsequent reproductive performance of high-producing Holstein cows. Theriogenology 61:1559-1571.

Simmons, C. R., W. G. Bergen, M. J. VandeHaar, D. J. Sprecher, C. J. Sniffen, E. P. Stanisiewski, and H. A. Tucker. 1994. Protein and fat metabolism in cows given somavubove before parturition. J. Dairy Sci. $77: 1835-1847$.

Spicer, L. J., W. B. Tucker, and G. D. Adams. 1990. Insulin-like growth factor-I in dairy cows: Relationships among energy balance, body condition, ovarian activity, and estrous behavior. J. Dairy Sci. 73:929-937.

Staples, C. R., J. M. Burke, and W. W. Thatcher. 1998. Influence of supplemental fats on reproductive tissues and performance of lactating cows. J. Dairy Sci. 81:856-871.

Tanaka, T., M. Arai, S. Ohtani, A. S. Uemura, T. Kuroiwa, S. Kim, and H. Kamomae. 2008. Influence of parity on follicular dynamics and resumption of ovarian cycle in postpartum dairy cows. Anim. Reprod. Sci. 108:134-143.

Turino, L. N., R. N. Mariano, M. I. Cabrera, D. E. Scándolo, M. G. Maciel, and R. J. A. Grau. 2010. Pharmacokinetics of progesterone in lactating dairy cows: Gaining some insights into the metabolism from kinetic modeling. J. Dairy Sci. 93:988-999.

van Knegsel, A. T. M., H. van den Brand, J. Dijkstra, W. M. van Straalen, R. Jorritsma, S. Tamminga, and B. Kemp. 2007. Effect of glucogenic vs. lipogenic diets on energy balance, blood metabolites, and reproduction in primiparous and multiparous dairy cows in early lactation. J. Dairy Sci. 90:3397-3409.

VanRaden, P. M., and A. H. Sanders. 2003. Economic merit of crossbred and purebred US dairy cattle. J. Dairy Sci. 86:1036-1044.

Wolfenson, D., Z. Roth, and R. Meidan. 2000. Impaired reproduction in heat-stressed cattle: Basic and applied aspects. Anim. Reprod. Sci. 60-61:535-547.

Zamet, C. N., V. F. Colenbrander, C. J. Callahan, B. P. Chew, R. E. Erb, and M. J. Moeller. 1979. Variables associated with peripartum traits in dairy cows. I. Effects of dietary forages and disorders on voluntary intake of feed, body weight, and milk yield. Theriogenology 11:229-244.

Zulu, V. C., N. Toshihiko, and Y. Sawamukai. 2002. Insulin-like growth factor 1 as a possible hormonal mediator of nutritional regulation of reproduction in cattle. J. Vet. Med. Sci. 64:657-665. 